\title{
Influential Factors on the Market Value of Residential Properties
}

\author{
Nadja Ferlan, Majda Bastic, Igor Psunder
}

\author{
University of Maribor \\ Smetanova 17, SI-2000 Maribor \\ E-mail.nadja.ferlan@um.si; majda.bastic@um.si; igor.psunder@um.si
}

cross $^{r e f} \underline{\text { http://dx.doi.org/10.5755/j01.ee.28.2.13777 }}$

\begin{abstract}
When using sales comparison approach, it is crucial to apply adjustments based on the differences between the appraised and comparable properties. Estimating the significance of each adjustment is of key importance for performing credible valuation. Adjustments should include factors such as location, physical and functional characteristics of residential properties and external influential factors. The aim of the article is to determine importance of influential factors and to quantify adjustments that arise from selected factors. Analytical results about the importance of factors influencing the appraised value of residential properties as perceived by different experts are presented in the empirical part of the article. The following factors were included in the study: orientation, views from the property, noise, number of storeys, and the age of the building. Data needed in the study were collected through interviews with authorised real estate appraisers, court sworn appraisers and real property agents. The key scientific problem was to determine mathematical functions for adjustment that arise from the storey of an apartment and from the age of the building. The findings of the study indicate that the location in relation to the distance from the city centre is the most important influential factor on the property value, similarly as in other countries across the world. Furthermore, the survey results show that the impact of the views and noise on the residential property value in Slovenia is also comparable with other studies. Results on the quantification of adjustments expectedly show that prices rise per storey in case there is an elevator in the building, but the result is opposite in case there is no elevator in the building. Results also show the influence of age on the value of the building. Based on mean values a linear function of annual depreciation rate has been set, which is the key novelty of the research. This function and the adjustments presented in the article are usable in valuation practice.
\end{abstract}

Keywords: Real Estate Appraisal, Residential Properties, Sales Comparison Approach, Influential Factors, Statistical Analysis.

\section{Introduction}

Real estate appraisal is the process of developing an opinion regarding the value of real property based on the knowledge, experience and professional assessment of value by real estate appraisers. While performing credible estimating, it is essential that appraisers use approaches specified by the International Valuation Standards (IVS).

When determining real and objective estimates of the value of residential properties, it is important that real estate experts gain information about the current situation of the real estate market, changes in construction and the impact of macroeconomic and demographic factors on price trends pointed out by Golob, Bastic \& Psunder (2012).

To estimate the value of residential properties it is crucial to determine the influence of factors that are associated with the housing characteristics and the influence of external factors on the value of residential properties. When using the sales comparison approach, market value is estimated by comparing properties similar to the subject property that have recently been sold, are listed for sale, or are under contact. Comparative analysis focuses on similarities and among properties and transactions that affect value (Appraisal Institute, 2013).

Sales comparison approach is the most accurate method if comparable sales are completed in the independent market and if as few adjustments as possible are applied. Numerous adjustments could distort the clarity of appraising, whereas the selection of inappropriate adjustments could lead to wrong conclusions. In the selection of adequate influential factors, it is essential for appraisers to possess a sufficient amount of reliable data about recent sales. Thus, the value of residential properties depends on the type of influential factors chosen by the real estate experts and the contribution of these factors to the final value of residential properties. When using the sales comparison approach, real estate experts face the problem of determining influential factors and estimating their influence on real estate value. Determination of housing characteristic and external factors is of key importance for performing credible valuation.

Before the changes in IVS (2013), the characteristics of residential properties and other factors were joined in the following basic components (called elements of comparison): real property rights conveyed, financing terms, conditions of sale, expenditures made immediately after purchase, market conditions, location, physical characteristics, functional characteristics, economic characteristics and non-realty components of value. In the IVS (2013), the aforementioned elements were joined and allocated into five components, which are reflected in the valuations. Changes in standards did not affect the changes in factors, which appraisers considered in the appraising of residential properties.

Adjustments to the market prices can be expressed in absolute value or in percentages. Percentile adjustments are mainly used when prices are adjusted due to transferred 
ownership rights; differences in financial, sales, and market conditions; and differences in property location. Differences in functionality, physical characteristics, and financial terms are expressed in absolute values. It should be mentioned that appraisers should place all of the adjustments onto common denominators and thus increase the clarity of valuation. Ventolo \& Williams (2005) have warned against adjustments, founded only on the subjective valuation (i.e. rule-of-thumb), although some appraisers in the property market also use this approach when adjusting values. The use of quantitative and qualitative methods is particularly important in the process of value adjustments and market data analysis, the latter also being a crucial decision-making factor in the process.

Quantitative methods present an advantage over qualitative ones, as they are based on mathematical and statistical data analysis. The Appraisal Institute (2013) advocates the following quantitative methods: paired data analysis, grouped data analysis, statistical analysis, graphic analysis, trend analysis, cost analysis, secondary data analysis, direct comparison, and capitalization of rent differences. Among the qualitative methods, Ventolo \& Williams (2005) to the greatest extent emphasised the paired data analysis method, which is an excellent tool when there are sufficient data available for the adjustment of value. Qualitative methods are based on attributive valuation and are used as a supplement to quantitative methods or in such cases when quantitative methods are not possible to be performed (Appraisal Institute, 2013).

Usually adjustments are still based on experience, but having in mind more accurate appraisal we started present research in which we intended to quantify some of important adjustment. The main aim of our research was to determine importance of influential factors and to quantify adjustments that arise from selected factors.

Following the findings of other authors (which are stated in the next chapter) those selected factors were included in the study: orientation, views from the property, noise, number of storeys, and the age of the building.

In the empirical part of the article we defined importance of influential factors, but also quantified adjustments that arise from those factors. Data needed in the study were collected through interviews with authorised real estate appraisers, court sworn appraisers and real property agents.

The key scientific problem was to determine mathematical functions for adjustment that arise from the storey of an apartment and from the age of the building which we consider as main original contribution to the appraisal science and profession.

\section{Literature Review}

Some studies can be found in the literature with the objective of examining an influence of different factors on the value or sales price of residential properties. Nachmen (2007), Ventolo \& Williams (2005), and Rodgers (1994) stated that the most important are adjustments due to the size, view, condition, and age of the residential property (physical characteristics of a property), appeal of architecture, the age of the building, and parking (or traffic). Buriskiene, Rudzkiene \& Venckauskaite (2011) stressed the location and prestige of a property, the age of building, type of house (construction of external walls), ecological state of a district (air pollution and noise level) and other factors such as number of storeys, number of rooms and total useful area of a property. Nachmen (2007) also emphasised the location of the property (including the reputation of the neighbourhood) and convenience (including functional characteristics). Nachmen (2007) also emphasised the location of the property (including the reputation of the neighbourhood) and the convenience (including the functional characteristics). Ventolo \& Williams (2005) have additionally investigated the impact of the type of heating and cooling as well as outdoor areas, such as the terrace and atrium. Rodgers (1994) has included in the adjustment process also ventilation, attic, and fireplace as important factors for a particular group of buyers. Eksioglu, Cetintahra \& Cubukcu (2014) emphasised the importance of the environmental aesthetic value of a street. They investigated the relation between the environmental aesthetic value of a street and the estimated house prices. Langerholc \& Grum (2012) list natural factors among the most important factors influencing the value of property, which included not only noise, amount of sunlight, and view, which were already taken into account in estimating the value of residential properties, but also avalanche, flooding, number of foggy and clear days, odour, windiness, quality of air, and the occurrence of hailstorms and sleet. Authors have examined the influence of these factors on the value of properties and the satisfaction of users with the properties. Important determinants of users' satisfaction with the properties are also the quality of neighbourhood facilities such as schools, public transport, street lighting, and access to neighbourhood facilities such as supermarkets, post offices, and corner shops (Parkes et al., 2002).

Location of property according to neighbourhood is the most important factor in the evaluation of value and represents one of the most demanding elements of analysis, which was proven by Mbachu \& Lenono (2005). Namely, $73.3 \%$ of all interviewed property owners have specified that location is a very important factor in the value of a property. Haider \& Miller (2000) examined cases in the United States and Australia and found that house prices fell dramatically with distance from the central business district (CBD) of a city.

It is also noted that neighbourhoods located in the industrial zone are less liveable then those in the urban centre and suburban areas (Chen et al., 2013). People take neighbourhood reputations into account when making their choices of where to live, to work, or to locate a business (Wacquant, 1993 as cited in Permentier et al., 2008). In his study in Portugal, Costa Pinto (2000) revealed that the residents of stigmatised neighbourhoods thought that the location and the poor accessibility of their neighbourhoods were responsible for their negative reputation.

In the appraising of the property value, the importance of property location is influenced by various factors: distance to work, proximity of health institutions and other important facilities, proximity of public transport, good traffic connection, parking, quiet neighbourhood, view, orientation, tidiness of neighbourhood, and green environment (Appraisal Institute, 2013).

A very important factor in the property appraising is the traffic connection between the property location and town 
centre or other business and shopping centres as well as work location. The influence of this factor on rent and consequently on the value of residential properties was proven through hedonic regression analysis by Frew \& Wilson (2002) in Portland, Oregon. The authors proved that the properties, located in the suburbs about 3.5 miles away from the freeways and 5 miles from the freeway intersection, have very high rent and consequently high price, comparable to the properties in the town centre. In larger towns with efficient public transportation (bus and underground lines), the proximity to public transportation stops played an important part in the purchase of properties. The findings of a study in Toronto, Canada, by Haider \& Miller (2000) revealed that the property value declines with the distance from the subway. The importance of the number of parking spaces in the near vicinity in terms of the property prices was also proven. The influence of the presence (Mak, Choy \& Ho, 2010) and size of parking spaces on property price (Cirman, Pahor \& Verbic, 2015) has a positive effect on the property price.

Another significant factor influencing the value of residential properties is the view, which depends on the viewed subjects and on the type of view. This factor was examined in the study of Brown et al. (2011) across various parts of the United States of America. They examined the impact of an ocean view, lake view, and golf course view on the value of real estate. They found that residential properties with a full view reached considerably higher prices in comparison with the properties with partially or obstructed views. Also important is the distance of viewed natural areas from the residential property. Numerous studies indicate that urban residents enjoy living near natural water features (Stokols et al., 2003) such as rivers, lakes and ponds (Jim \& Chen, 2006; Wen et al., 2005; Huang \& Yin, 2015). Their research results show that proximity to natural water features has a positive effect on housing prices.

A decrease in house prices with an increase of distance from the ocean was also found in a study of single family houses in New Hewen County (Acharya \& Bennett, 2001). Views with greater diversity (i.e. more land cover) were found to increase property values in the state of Wyoming, United States (Bastial et al., 2002) and in Sha Tin, Hog Kong (Mak, Choy \& Ho, 2010). The findings of a study by Jim \& Chen (2010) in Hong Kong revealed that the vicinity of parks and other green areas contributed considerably to apartment sale prices. Residents were willing to pay 14.93 $\%$ more to have a neighbourhood park nearby. In addition, a view of the park area from an apartment raised the apartment price by an extra $1.95 \%$. The influence of an ocean view on the value of residential properties was analysed in a study in Bellingham, Washington. (Benson et al., 2000). They found that the open view of the ocean could increase the market value of residential properties by $59 \%$, partially obstructed by $29 \%$ and heavily obstructed by $8 \%$, compared with the properties without an ocean view.

The influence of the floor level on the residential property value was examined in the hedonic regression analysis in Hong Kong (Choy, Mak \& Ho, 2007), a town with skyscrapers. Findings revealed that properties on higher floors with consequently better views are more expensive and easier to sell. The size of a property is usually expressed by the number of rooms and the area of property space. The number of rooms in a property (defining a type of apartment) is an important piece of information for future users. Purchase decision is undoubtedly linked to the size of the household and the buyer's financial means (Psunder \& Ferlan, 2009).

Psunder \& Ferlan (2009) also revealed that residential property users consider running costs to be highly important. Running costs include the cost of heating; as a result, valuations should additionally consider the type of heating (distance heating, gas, oil, electricity), mainly due to the costs incurred by the users. A factor with increasing impact on the property value is the energy efficiency of buildings, which is reflected in the running costs. In order to achieve energy efficiency, it is crucial to reduce the amount of energy required to operate the existing residential facilities. Construction and sales of energy-saving and passive houses are implemented increasingly more frequently. Energy restoration is most often accomplished in the renovation of older residential properties with poor heating protection and systems; in newer buildings, such an aspect is necessary due to the large energy losses occurring as a result of inadequate construction. Renovation offers opportunities to increase building energy efficiency and reduce greenhouse gas emissions from existing buildings (Meijer et al., 2009). Kovic \& Praznik (2008) analysed the effect of the renovation of a building with 50 apartments, built in 1960, from the energy and cost reduction viewpoint. They found that the loss of heat can be reduced by at least $30 \%$ just by following basic measures of energy restoration. The administration of complete energy restoration of a multi-apartment building and the achievement of lowenergy or passive levels could reduce the consumption of energy for heating by 70-90\%. The described renovation has contributed to a higher property value by at least $7 \%$ in the examined property, which presents an immediate return on investment.

Nevertheless, greater consideration should also be given to everyday routines associated with renovations rather than just energy efficiency (Judson et al., 2014). When adjusting the values, appraisers undoubtedly perform adjustments as a result of differences in the physical characteristics between evaluated and compared residential properties as well as a result of the differences in the physical status of residential buildings. The value of adaptation work is therefore equal to the expenditure, which a user should set aside for the renovation of overused apartments and buildings (Psunder \& Torkar, 2007). If the specific or compared properties are not renovated, the costs for the removal of physical deficiencies and overuse should be calculated. Physical overuse can be reparable or irreparable. In the former case, it is sensible to correct the overuse with maintenance work, whereas in the latter case, it is not (Technical Information Paper, 2012). It is true that buildings should be subjected to regular maintenance as well as larger investment repair work, depending on the age and life span of individual construction elements in the building, as defined in the regulations on maintenance standards of residential buildings and apartments (Official Gazette RS, 20/2004). The largest and most expensive investment maintenance work on existing residential buildings is the restoration of wall and roof frontage; 
therefore, these two interventions represent the largest influence on the value of residential properties.

When appraising the dilapidation of a building, the most important factors are the condition of the building and its age. The age of buildings was incorporated into the hedonic analysis by Brandt \& Maenning (2011) in Hamburg, Germany; Janmaat (2007) in Wolfville, Canada; and Choy, Mak, \& Ho (2007) in Hong Kong, China and into Meta regression analysis by Sirmans and MacDonald. (2006) in United States. As expected, it was revealed that the age of buildings is negatively correlated with the value of residential properties. This means that the prices were decreasing with the increasing age of buildings. The influence of building age on the value of residential properties in Great Britain was examined by Fletcher, Gallimore \& Mangan (2000). They found that the property values on average decrease by $0.26 \%$ per year.

Appraisers of residential properties also consider the appeal of the building architecture. The study on the apartment users in Hong Kong by Liu (1999) has revealed that the architectural appeal of the building and the incorporation of architectural design in the environment are important, yet not decisive factors in the property purchase decisions.

Economic characteristics considered in the appraising of properties include negative environmental factors, such as the proximity of industrial facilities, busy roads, and business and shopping centres. The influence of busy roads on the value of apartments in Hong Kong was reported in 2010 by Jim and Chen. They found that the view of the road with heavy traffic reduced the value of apartments by $1.39 \%$. Another significant negative factor on residence value is noise. Total noise pollution is the result of the operation of all noise sources (e.g. roads, railways, industry sources) in a given area and represents the true burden of population and areas with noise. Areas of noise pollution are those that exceed the acceptable limit of the daily noise level $(55 \mathrm{~dB})$ and nighttime noise (45 dB). (Epi Spektrum, 2009). In the study of Swedish residential properties, Wilhelmsson (2000) found that the residential properties in locations where noise exceeded the acceptable levels by $17 \mathrm{~dB}$ faced up to $30 \%$ lower prices. Theebe (2000) investigated apartments in the east part of Holland and revealed that apartments built in locations with 66 to $70 \mathrm{~dB}$ noise levels demonstrated a $0.7 \%$ lower price, $3.8 \%$ lower prices in locations with noise levels between 71 and $75 \mathrm{~dB}$, and $5 \%$ lower prices for apartments in locations with noise level of more than $75 \mathrm{~dB}$, compared to apartments built in the areas with a noise level between 41 and 65dB. Brandt and Maenning (2011) in the study in Hamburg revealed that the prices of residential properties are falling by $0,23 \%$ due to the $1 \mathrm{~dB}$ increase in noise pollution. That means that properties in locations with more than a 70 $\mathrm{dB}$ noise level demonstrated an approximately $3.90 \%$ lower price in comparison with a location of comparable level.

After reviewing the literature, it can be concluded that many different types of factors have great impact on the value of residential properties. Because the value of residential properties depends on the type of influential factors and of the contribution of these factors to the value of a property, we decided to carry out a survey among authorised real estate appraisers, court appraisers in civil engineering, and real estate agents. All mentioned experts are well-informed participants of the real estate market. In addition to the authorised real estate appraisers and court-sworn appraisers, whose responsibilities include providing a professional estimation of residential properties value, real estate agents are also important experts. Their job is to provide informal opinions about residential property values, which is the starting point for negotiation between buyers and sellers.

The purpose of the study was to find factors which significantly influence the value of residential properties. Furthermore, we sought to explore the impact of factors that have been the subject of studies carried out in various parts of the world. We also examined whether the impact of selected factors is comparable to the impact of factors revealed in reviewed studies. The findings of our research should be well accepted by all real estate experts.

\section{Research areas and Methodology}

\section{Research Framework}

In the study we focused on the impact of following factors: residential property orientation, views from the residential property, noise level, residential property floor level, and the age of the building on the value of properties, which were studied in the aforementioned studies. In order to facilitate appraisers' future estimation of residential property value, a negative correlation between the age of the residential properties and their values was determined.

\section{Sample and Data Collection}

The target population consists of authorised real estate appraisers, court-sworn appraisers in civil engineering, and real estate agents. A questionnaire was sent to each of the 74 authorized real estate appraisers, listed in the register of certified real estate appraisers in the Slovenian Institute of Auditors and 300 court-sworn appraisers in civil engineering, listed in the directory of court appraisers at the Ministry of Justice. Data from the property agents was collected with the support of the Slovenian Chamber of Commerce, which sent an electronic version of a questionnaire to approximately 180 registered real estate agents, who were members of the Chamber. We obtained 96 usable questionnaires, which represent a $13.40 \%$ response rate.

The questionnaire consisted of two groups of questions. The first group of questions referred to general information about the respondents. The second group of questions was used to obtain data related to factors' impact on the property value. The factor impact was evaluated by the experts on a five-point scale, with 1 representing no impact on the value and 5 representing a high influence on the evaluation of the apartment value. Open questions were added in order to obtain data about the percentage change in the assessed value of apartments due to different orientations, views, floors, age of apartments, and noise level.

Data in the study were analysed using the SPSS programme (a programme for statistical analysis) and with MS Excel (a programme for electronic data analysis) for the graphical presentation of the results. Univariate analysis was used to examine the influential factors of properties. In order to set an annual depreciation level of property values due to its age in an average maintained building, a linear interpolation in the MS Excel programme was used to determine trend function. 
Data on interviewed subjects

The sample included $51 \%$ of real estate agents, $26 \%$ of authorised real estate appraisers, and $22.9 \%$ court-sworn appraisers. In this study, 12 regions were grouped into four similar areas according to the purchasing power of the population and the environmental characteristics of individual regions, which could affect the value of apartments.

\section{Limitations of the study}

In this study, we considered only residential properties which are located in urban areas, with the influence of neighbourhood and road noise. The industrial, aircraft and other types of noise have not been taken into account. We also consider that residential buildings are of usual height, but not skyscrapers. Other limitations beyond those mentioned above were not considered.

\section{Results}

In the following we are going to show the results of our research. In Table 1, the means and standard deviations of factors are provided, starting with the factor of the greatest importance. The most important factor is 'location in relation to the distance from city centre,' with the highest mean of 4.67. It is followed by 'parking place' and 'absence of negative factors' (e.g. proximity industrial facilities). These results show that the respondents consider distance from city centre to be the most important factor in property appraising. Additionally, the factors that also ranked very high, were available parking (mean is 4.33), absence of negative environmental factors (average value $=4.18$ ), and the floor level in buildings without elevators (mean is 4.12). In the buildings with elevators, the importance of the factor of floor level was decreased (mean is 3.08). Among the first 10 factors were also the layout of property, size of residential property (number of rooms) and quietness (absence of noise), whose means are close to 4 , as well as adequate level of apartment maintenance, which includes mostly maintenance of built-in elements (regular keep) and building maintenance, which depends on the performed maintenance work. In ninth place are running costs, which depend on energy design or renovation work done. The results indicated that location factors, such as proximity of public transport, health institutions, and cultural and other important buildings were less important in appraising the value of properties by property experts.

Table 1

Average Importance of Influential Factors

\begin{tabular}{llcc}
\hline No. & Influential factors & Mean & $\begin{array}{c}\text { Standard } \\
\text { deviation }\end{array}$ \\
\hline 1 & $\begin{array}{l}\text { Location in relation to the distance from } \\
\text { city centre }\end{array}$ & 4.67 & 0.749 \\
2 & Parking place & 4.33 & 0.867 \\
3 & Absence of negative factors & & \\
& (e.g. proximity of industrial facilities) & 4.18 & 0.995 \\
4 & Floor level & & \\
& (in buildings without an elevator) & 4.12 & 0.914 \\
6 & Layout of property & 4.04 & 0.798 \\
7 & size of property (number of rooms) & 4.02 & 0.812 \\
\hline
\end{tabular}

\begin{tabular}{llcc}
\hline No. & Influential factors & Mean & $\begin{array}{c}\text { Standard } \\
\text { deviation }\end{array}$ \\
\hline 8 & Level of maintenance of apartment & 3.91 & 0.884 \\
9 & Running costs & 3.91 & 0.912 \\
10 & Level of building maintenance & 3.81 & 0.829 \\
11 & Central heating & 3.75 & 0.940 \\
12 & Tidiness of immediate neighbourhood & 3.72 & 0.791 \\
13 & Proximity of schools and kinder gardens & 3.7 & 0.848 \\
& Traffic connection & & \\
14 & (proximity to main roads) & 3.69 & 0.990 \\
15 & Energy efficiency of the building & 3.68 & 0.814 \\
16 & Open view & 3.67 & 0.868 \\
17 & Age of the building & 3.54 & 0.876 \\
18 & Orientation (direction) & 3.46 & 0.976 \\
19 & Terrace & 3.37 & 0.904 \\
20 & Public transportation & & \\
& (proximity to stops) & 3.36 & 1.061 \\
21 & Proximity to health institutions & 3.34 & 0.833 \\
22 & Proximity to shops & 3.31 & 0.837 \\
23 & Floor level & & \\
& (in building with an elevator) & 3.08 & 0.992 \\
24 & Construction material & 3.05 & 0.966 \\
25 & Proximity to work & 3.04 & 1.081 \\
26 & Proximity to cultural and other important & & \\
& buildings & 2.24 & 0.926 \\
\hline
\end{tabular}

According to the theoretical starting points, an open view from the residential property and quiet neighbourhood are increasingly more important in property appraising. We examined the respondents' estimates of the impact of orientation, view, and noise on the value of residential properties (see Table 2). The analysis revealed that bad orientation resulted, on average, in a $10 \%$ decrease in the property value. Of the experts interviewed, $52 \%$ shared an opinion that the property value decreased between 5 and 15 $\%$ due to the non-optimal orientation, whereas another $39 \%$ stated that such decrease in value was less than $5 \%$. The smallest proportion of real estate experts $(9 \%)$ attributed a more than $15 \%$ decrease in the value of residential properties to the non-optimal orientation of residential properties.

An average decrease in the value of residential properties due to noisy surroundings is approximately $12 \%$ in comparison with the location with acceptable noise level. Almost $40 \%$ of all respondents estimated a $15 \%$ reduction of property value due to the noise exposure or more.

An open view contributed to the average increase of approximately $12 \%$ in the value of residential properties, although this percentage differed by region. An increase in the value by up to $40 \%$ was assessed for properties with an open view to sea.

Table 2

Influence of Orientation, Noise, and View on the Value of Residential properties

\begin{tabular}{lcc}
\hline & Mean & $\begin{array}{c}\text { Standard } \\
\text { deviation }\end{array}$ \\
\hline $\begin{array}{l}\text { Change of the value of residential properties if } \\
\text { the cardinal orientation is not optimal }\end{array}$ & -9.86 & 6.982 \\
$\begin{array}{l}\text { Change of the value of residential properties if } \\
\text { they face a noisy street or road }\end{array}$ & -12.27 & 6.957 \\
$\begin{array}{l}\text { Change of the value of residential properties } \\
\text { with an open view }\end{array}$ & 12.35 & 7.956 \\
\hline
\end{tabular}


Figure 1 shows the percentage of respondents choosing a particular orientation direction as optimal. Data analysis revealed that $43.8 \%$ of real estate experts consider southwest orientation as optimal, and $26.3 \%$ stated that southeast orientation is optimal. Also suitable was orientation to the south, as the living areas are exposed to sunlight for a longer part of the day. The least desired orientations were northeast and northwest. Real estate experts did not choose north orientation.

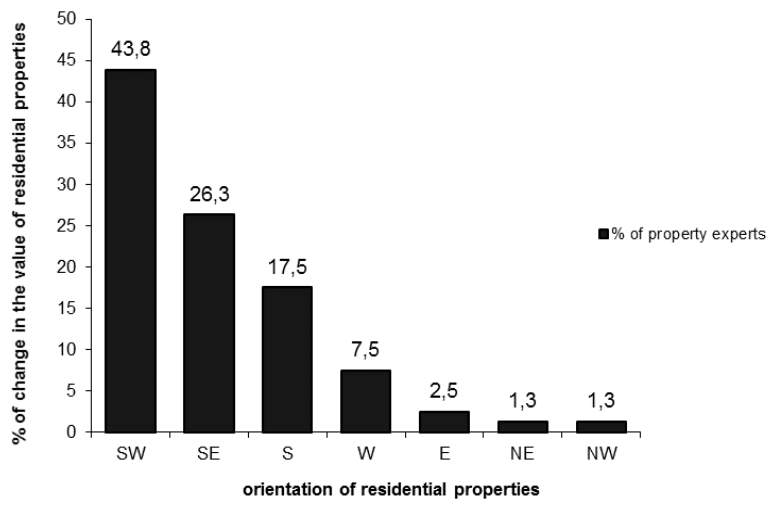

Figure 1. Optimal Cardinal Direction for Orientation of Residential Properties

Real estate experts have also estimated changes in the value of residential properties according to the floor level for a four-storey building without an elevator and for a six-storey building with an elevator. Calculated average changes in the value of residential properties according to the floor level of the four-storey building without an elevator have expectedly revealed a $2.46 \%$ average increase for first-floor residential properties in comparison to the ground-floor residential properties (see Figure 2). It can be concluded that groundfloor properties are less desired than those on the first floor, most probably due to the higher exposure to the outside world. The value of residential properties from the second floor to the fourth floor decreased. The average decrease in the value of properties on the fourth floor was $8.18 \%$. It was confirmed that access to stairs as the only type of access to the properties is not desirable for the majority of people, particularly for older ones. The average decrease in the value of properties on the second to fourth floors was $3.54 \%$.

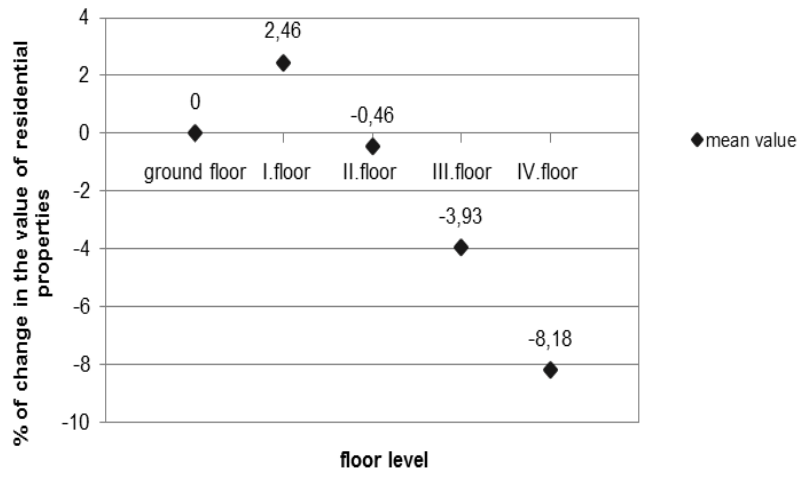

Figure 2. Average Change of the Floor Level on the Value of Apartment in Buildings Without an Elevator
The majority of respondents estimated an increase in the value of a property on a higher floor level in the building with an elevator (see Figure 3). Compared to residential properties on the ground floor, the largest increase in value was for the first-floor properties, on average by $2.72 \%$. The average increase in property value on other floors was slightly smaller. The average increase in value for individual floor level was $1.3 \%$ for properties on the first to sixth floors in a building with an elevator. The results also indicated that approximately $18 \%$ of property experts shared the opinion that the value of residential properties does not depend on the floor levels in buildings with an elevator.

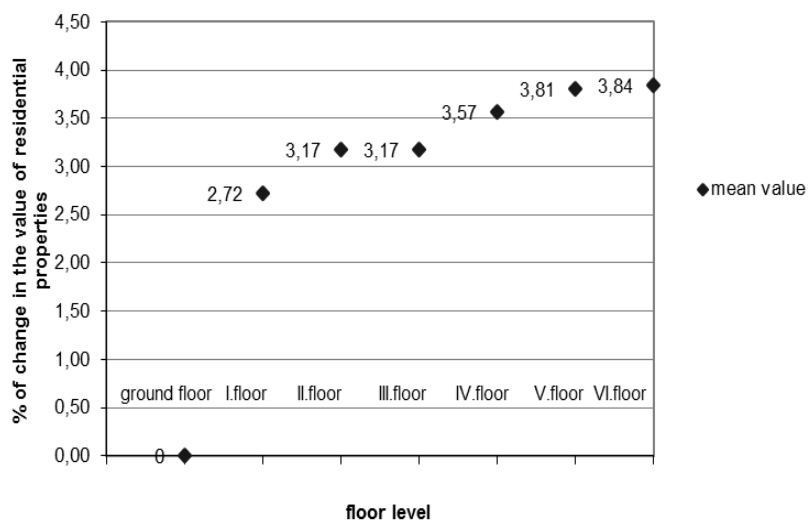

Figure 3. Average Change of the Floor Level on the Value of Residential Properties in Buildings with an Elevator

When examining the impact of building age on the value of properties in an averagely maintained building, we revealed a negative relationship between the building age and its value (see Figure 4). Standard deviations show that the values of the residential properties in buildings older than 30 years were widely dispersed, indicating that the respondents' estimates were quite different. In order to set an annual depreciation rate of property value, average values were used in polynomial interpolation in order to find linear regression function. For easier use of this function in practice, it has been calculated from the point of origin (0). Determination coefficient R2 is 0.9492 , indicating that approximately $95 \%$ of variance in percentage change in property value was explained by the variance of residential properties age. The obtained linear function is $y=-0,3214 x$, where $y$ represents the percent of change in the value of apartments, and $\mathrm{x}$ represents the age of the building in years. A decrease of property value due to the annual depreciation level is $0.32 \%$ in an averagely maintained building in Slovenia. Linear function reveals that, according to the property experts' estimates, the value of an averagely maintained 60-year-old residential building is around $80 \%$ of the value of the new building. Moreover, buildings at the end of their life span, after 150 years of use, still carry a high market value of around $52 \%$. 


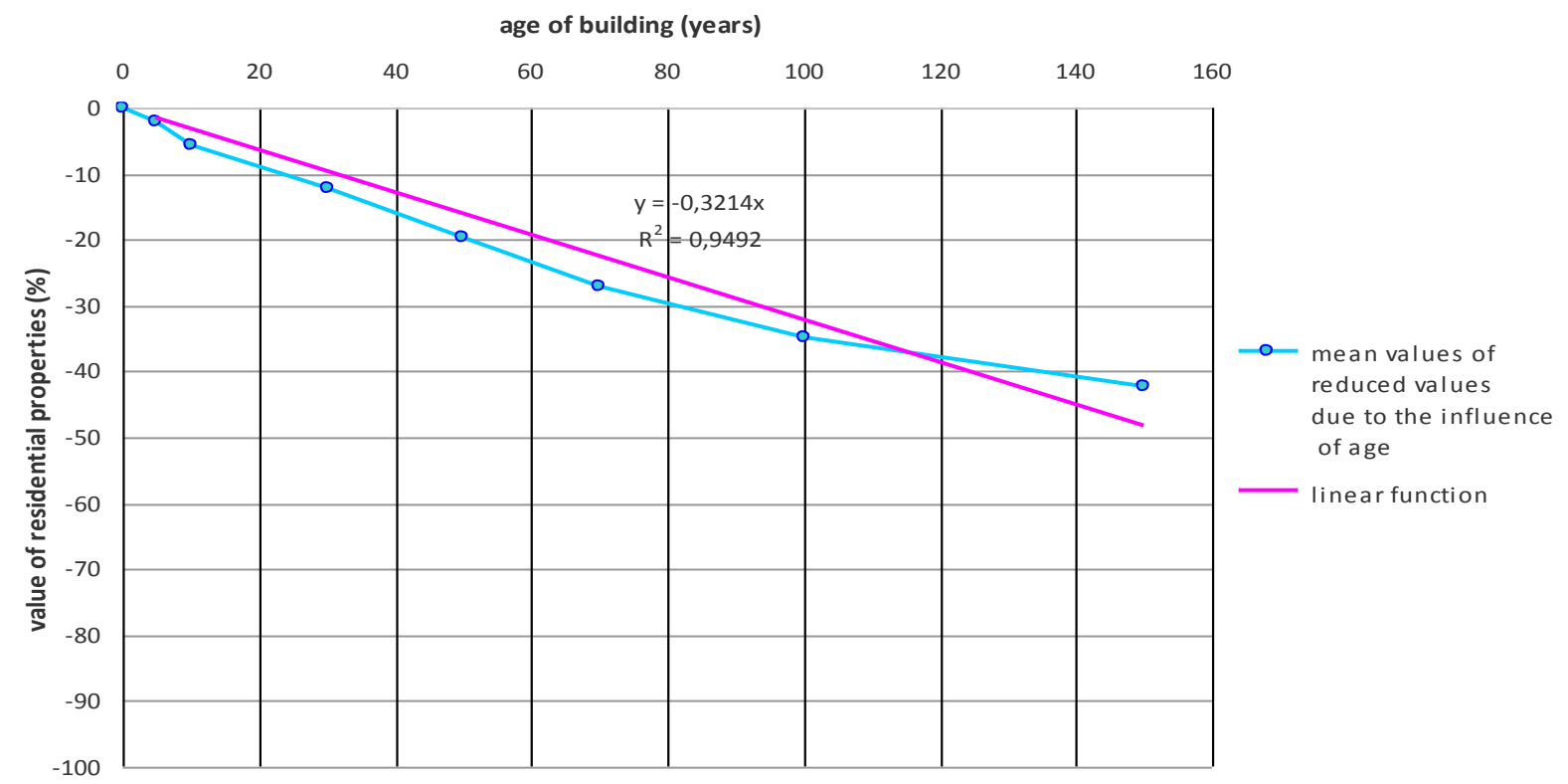

Figure 4. Functional Presentation of the Impact of the Building age Onto the Residential Properties Value

\section{Discussion and Conclusions}

The findings of the study on the importance of influential factors in appraising of residential properties value indicate that the location in relation to the distance from the city centre is the most important influential factor on the property value, similarly as in other countries across the world. As the distances in larger cities between the city centre and suburbs are larger than in the cities, included in the survey, it can be assumed that the differences in the values of residential properties are even bigger. As the real estate experts did not estimate proximity to work, shops, health institutions, and other important buildings as important factors, it can be assumed that these factors are to a great extent already included in the appraising of location in relation to the distance from city centre, which is consistent with the findings in other studies. In addition to location, available parking places was found to be a factor with a great impact on the value of residential properties.

Analysis has revealed that the absence of negative factors from the environment (e.g. proximity industrial facilities), noise, and good physical status of apartments were also very important. Furthermore, the appraisers attributed high importance to the energy-efficient construction following new guidelines and changes in the legislation on the efficient use of energy. An energy-efficient building contributes to energy savings, which results in lower energy use and consequently lower running costs.

On the basis of comparison with theoretical findings, it can be found that the impact of the views on the residential property value in Slovenia was highly comparable to the impact of a good views in studies from other countries. The respondents estimated up to a $40 \%$ increase in the value of residential properties with a sea view, while the average increase in value was estimated at approximately $12 \%$.

Not optimal orientation, which is related to the small amount of sunlight residential properties receive during the day, was attributed to a $15 \%$ decrease in a residential property value in almost all Slovenian regions. Interviewed experts shared the opinion that southwest and southeast are the most desirable orientations of residential properties, providing the best natural lighting of living areas. We found that authors in other studies didn't analyse the impact of orientation on the value of residential properties. They found orientation important only in terms of properties' views of the sea, parks, and others natural elements.

Compared to the theoretical review of the impact of noise on property value, it can be noticed that real estate experts in Slovenia attribute high importance to quiet location, because almost $40 \%$ of all respondents estimated a $15 \%$ reduction of property value or more. The results of our study show that the impact of noise on the property value in Slovenia is similar to the results from the study of Swedish residential properties, where residential properties in locations with a noise level of more than $70 \mathrm{~dB}$ achieved up to $30 \%$ lower price, in comparison with locations with acceptable levels of noise. Other studies indicate lower increase in prices due to noise pollution. It can be noticed that the estimate of the impact of noise on the property value in Slovenia was higher then expected.

The findings in the analysis indicate that the majority of respondents think that the presence of an elevator in buildings increases the value of residential properties on higher floor levels, which is similar to the study in Hong Kong (Choy, Mak \& Ho, 2007), which is a city with many high-rise buildings. According to the evidence of the issue, the influence of floor level has not been included in the majority of studies.

In our research we established average change in value per floor level for residential properties in buildings with an elevator and without it. We expect that the results can be directly transferred into appraising profession.

Function, which was used to determine the impact of age of a building on the property value, expectedly revealed 
a negative influence of age at $0.32 \%$, which is similar to the findings of Fletcher, Gallimore \& Mangan (2000). For better transferability into appraisal practice we set up linear function which highly corresponds with the study results.

We assume that the results of the analysis of the importance of residential property characteristics and other influential factors which influence the value could help real estate experts to select and estimate the adjustments made to the sale prices of comparable residential properties. Namely, experts will be able to determine a set of factors and their influence on value with greater certainty.

The results of our research can be applied to statistical modelling for estimating the relationship between residential property characteristics and other influential factors. Furthermore, the survey results may also be important for a parameterized estimate of the value.

The expectations of buyers when purchasing properties are constantly changing as a result of changes in the standard of living and lifestyle, changes in the construction of buildings and environmental legislation, and changes in the regulations on the rational use of energy and other factors, which influence their needs. Based on all of the above mentioned, it can be expected that the importance of factors will probably change; therefore, a study should be repeated over various time periods.

\section{References}

Acharya, G., \& Benett, L. L. (2001). Valuing open space and land - use pattern in urban watersheds. Journal of Real Estate Finance and Economics, 22 (2/3), 773-237. https://doi.org/10.1023/A:1007843514233

Appraisal Institute. (2013). The Appraisal of Real Estate, 14th ed., Chicago: Appraisal Institute.

Bastial, C. T., McLeod, D. M., Germino, M. J., Reiners, W. A., \& Blasko, B. J. (2002). Environmental amenties and agricultural land values: a hedonic model using geographic information system data. Ecological Economics, 40(3), 37-349.

Buriskiene, M., Rudzkiene V., \& Venckauskaite, J. (2011). Models of factors influencing the real estate price. Environmental Engineering, The 8th International Conference, 873-878.

Benson, E. D., Hansen, J. L., \& Schwartz Jr., A. L. (2000). Water View and Residential Property Values. The Appraisal Journal, 68, 260-271.

Brandt, S., \& Maenning, W. (2011). Road noise exposure and residential property prices: Evidence from Hamburg. Transport Research Part D - Transport and Environment, 16, 23-30. https://doi.org/10.1016/j.trd.2010.07.008

Brown P., MAI, MBA, RPA, \& McCabe, B., RPA. (2011). Current Issues Concerning View Attributes in the Appraisal of Real Estate, Travis Central Appraisal District, Retrieved Januar 15, 2013, from: http://www.taad.org/Appraisingwith-a-View.pdf

Chen, L., Zhang, W., Yu, J., \& Yang, Y. (2013). Disparities in residential environment and satisfaction among urban residents in Dalian, China. Habitat International, 40, 100-108. https://doi.org/10.1016/j.habitatint.2013.03.002

Choy, L. H. T., Mak, S. W. K., \& Ho, W. K. O. (2007). Modeling Hong Kong real estate prices. Journal of Housing and the Built Environment, 22, 359-368. https://doi.org/10.1007/s10901-007-9089-2

Cirman, A., Pahor, M., \& Verbic, M. (2015). Determinants of Time on the Market in a Thin Real Estate Market. Inzinerine Ekonomika-Engineering Economics, 26(1), 4-11. https://doi.org/10.5755/j01.ee.26.1.3905

Costa Pinto, T. (2000, June). Residential Contexts of Social Exclusion: Images and Identities. Paper presented at the International Research Conference of the Institute for Housing Research, Uppsala University. Gavle, Sweden. Retrieved March 5, 2014, from: http://www.kvarterloeft.dk/nyt/nyheder/image/ WS12_Costa_Pinto.pdf

Eksioglu Cetintahra, G., \& Cubukcu, E. (2014). The influence of environmental aesthetics on economic value of housing: an empirical research on virtual environments. Journal of Housing and the Built Envronment. Published in the internet version.

Epi Spektrum d.o.o.. (2009). Noise chart for Maribor town. Retried January 5, 2013, from the website of the municipality of Maribor: http://www.maribor.si/dokument.aspx?id=11178

Fletcher, M., Gallimore, P., \& Mangan, J. (2000). Heteroskedasticity in hedonic house price models. Journal of Property Research, 17 (2), 93-108. https://doi.org/10.1080/095999100367930

Frew, J., \& Wilson, B. (2002). Estimating the Connection between Location and Property Value. Journal of Real estate practice and education, 5, pp. 1, 17-25.

Golob, K., Bastic, M., \& Psunder, I. (2012). Analysis of Impact Factors on the Real Estate Market: Case Slovenia. Inzinerine Ekonomika-Engineering Economics, 23(4), 357-367. https://doi.org/10.5755/j01.ee.23.4.2566 
Haider, M., \& Miller, E. J. (2000). Effects of Transportation Infrastructure and Location on Residential Real Estate Values: Application of Spatial Autoregressive Techniques. Transportation Research Record: Journal of the Transportation Research Board, 1722, 1-8. https://doi.org/10.3141/1722-01

Huang, H., \& Yin, Li (2015). Creating sustainable urban built environments: An application of hedonic house price models in Wuhan, China. Journal of Housing and the Built Environment, 30, 219-235. https://doi.org/10.1007/s10901-0149403-8

International Valuation Standards - IVS [Mednarodni standardi ocenjevanja vrednosti]. 10 th ed. (2013), International Valuation Standards Committee. Ljubljana: Slovenian Institute of Auditors. Retrieved March 5, 2014 from: http://www.si-revizija.si/ocenjevalci/dokumenti/pravila_stroke/MSOV-2013.pdf

Janmaat, J. (2007). Factors affecting Residential Property Values in a Small Historic Canadian University Town. Retrieved August 15, 2012 from Munich Personal RePEc Archive, University of British Columbia Okanagan Web site: http://mpra.ub.uni-muenchen.de/6145/3/MPRA_paper_6145.pdf

Jim, C. Y., \& Chen, W. Y. (2006). Impacts of urban environmental elements on residential housing prices in Guangzhou (China). Landscape and Urban Planning, 78(4), 422-434. https://doi.org/10.1016/j.landurbplan.2005.12.003

Jim, C. Y., \& Chen, W. Y. (2010). External effects of neighbourhood parks and landscape elements. Land Use Policy, 27, 662-670. https://doi.org/10.1016/j.landusepol.2009.08.027

Judson, E., P., Iyer-Raniga, U., \& Horne R. (2014). Greening heritage housing: understanding homeowners`renovation practices in Australia. Journal of Housing and the Built Environment, 29, 61-78. https://doi.org/10.1007/s10901013-9340-y

Kovic, S., \& Praznik, M. (2008). Sanacija vecstanovanjskih stavb v pasivnem in nizkoenergetskem standardu, Institut ZRMK, d. o. o. Web site: http://www.gizrmk.si/Knjiznica/SANACIJA\%20VE\%C4\%8CSTANOVANJSKIH\%2 OSTAVB.pdf.

Langerholc, N., \& Grum, B. (2012). Stalisca o vplivih kljucnih naravnih dejavnikov pri vrednotenju nepremicnin s poudarkom na poplavnosti, [Opinions about key influential natural factors in real estate evaluation with an emphasis on flooding] Geodetski vestnik, 56(3), 482-498. https://doi.org/10.15292/geodetski-vestnik.2012.03.482-498

Liu, A. M. M. (1999). Residential satisfaction in housing estates: a Hong Kong perspective. Automation in Construction, 8, 511-524. https://doi.org/10.1016/S0926-5805(98)00098-3

Mak, S. W. K., Choy, L. H. T., \& Ho, W. K. O. (2010). Quantile Regression Estimates of Hong Kong Real Estate Prices. Retried March, 2016, from Urban Studies Journal Limited Web site: http://www.bre.polyu.edu. hk/BRE_workshop/pdf/Quantile\%20Regression\%20Estimates\%20of\%20HK\%20real\%20estate\%20prices.pdf https://doi.org/10.1177/0042098009359032

Mbachu, J. I. C., \& Lenono, N. (2005). Factors influencing market values of residential properties. (Paper presented at Research Week International Conference, Brisbane, Australia.) Retried July 20, 2012, from The Queensland University of Technology Web site: http://s3.amazonaws.com/ zanran_storage/www.rics.org/ ContentPages/ 65387467.pdf

Meijer, F., Itard, L., \& Sunikka-Blank M. (2009). Comparing European residential building stocks: performance, renovation and policy opportunities. Building Research \& Information, 37(5), 533-551. https://doi.org/10.1080 /09613210903189376

Nachmen, I. W. (2007). The Complete Guide to Financing Real Estate Developments. New York: McGraw - Hill.

Parkes, A., Kearns, A., \& Atkinson, R. (2002). What makes people dissatisfied with their neighbourhoods? Urban Studies, 39(13), 2413-2438. https://doi.org/10.1080/0042098022000027031

Permentier, M., Van Ham, M., \& Bolt, G. (2008). Same Neighbourhood ... Different View? A Confrontation of Internal and External Neighbourhood Reputations, Housing Studies, 23, 833-855. https://doi.org/10.1080/0267303 0802416619

Psunder, I., \& Ferlan, N. (2009). Subjektivno dojemanje vplivnih faktorjev pri ocenjevanju vrednosti nepremicninskih pravic. [Subjective perception of influential factors in evaluation of real estate rights values] In A. Kozar \& A. Belsak. (ed.). Book of abstracts from 20th annual congress Dealing in real estate: state, citizens, properties, (pp. 246 251), Ljubljana: real estate institute.

Psunder, I., \& Torkar, M. (2007). Ocenjevanje vrednosti nepremicninskih pravic [Valuation of real property]. Ljubljana: The Slovenian Institute of Auditors.

Rodgers, T. (1994). Property to Property Comparison. Appraisal Journal, 62, 64-67. 
Sirmans, G. S., MacDonald, L. (2006). The Value of Housing Characteristics: A Meta Analysis. Journal of Real Estate Finance and Economics, 33, 215-240. https://doi.org/10.1007/s11146-006-9983-5

Stokols, D., Grzywacz, J. G., McMahan, S., \& Phillips, K. (2003). Increasing the health promotive capacity of human environments. American Journal of Health Promotion, 18, 4-13. https://doi.org/10.4278/0890-1171-18.1.4

Technical Infomration Paper [Strokovno informativno gradivo], (2012). Ljubljana: Slovenian Institute of Auditors, Retried April 15, 2013, from: http://www.si-revizija.si/

Theebe, M. A. J. (2004). Planes, trains and automobiles: The impact of traffic noise on house prices. Journal of Real Estate Finance and Economics, 28, issue 2/3, 209-234. https://doi.org/10.1023/B:REAL.0000011154.92682.4b

Wen, H. Z., Jia, S. H., \& Guo, X. Y. (2005). Hedonic price analysis of urban housing: An empirical research on Hangzhou, China. Journal of Zhejiang University SCIENCE, 6A(8), 907-914. https://doi.org/10.1631/jzus.2005.A0907

Wilhelmsson, M. (2000). The impact of traffic noise on the single-family houses. Journal of Environmental Planning and Management, 43, 799-815. https://doi.org/10.1080/09640560020001692

Williams, L., Ventolo, Jr., \&Williams, M. R. J. D. (2005). Fundamental of real estate Appraisal, 9th Ed. Chicago: Real Estate Education Company.

The article has been reviewed.

Received in December, 2015; accepted in April, 2017. 